\title{
Identification and Partial Characterization of a New Luteovirus Associated with Rose Spring Dwarf Disease
}

\author{
Nidá Salem, Deborah A. Golino, Bryce W. Falk, and Adib Rowhani, Department of Plant Pathology, University of \\ California, Davis 95616
}

\begin{abstract}
Salem, N., Golino, D. A., Falk, B. W., and Rowhani, A. 2008. Identification and partial characterization of a new luteovirus associated with rose spring dwarf disease. Plant Dis. 92:508-512.

A number of viruses in the genera Ilarvirus and Nepovirus have been shown to be associated with specific diseases in rose, but many graft-transmissible rose diseases still have unknown etiologies. One of these diseases originally was detected by grafting from nonsymptomatic roses to Rosa multiflora indicator plants. Double-stranded RNAs (dsRNAs) were recovered and used as templates for cDNA synthesis and generating a cDNA library. Analysis of deduced amino acid sequences clearly positioned this virus as a member of the family Luteoviridae. The name rose spring dwarf associated virus (RSDaV) is tentatively proposed for the novel virus because the symptoms of this virus on $R$. multiflora are consistent with previous descriptions of rose spring dwarf disease (RSD). Phylogenetic analysis revealed a close relationship of RSDaV with members of the genus Luteovirus. Aphid transmission studies identified the rose-grass aphid (Metapolophium dirhodum) and yellow rose aphid (Rhodobium porosum) as vectors for this new virus. Host range data showed that RSDaV has a host range including both monocots and dicots. A specific reverse-transcription polymerase chain reaction assay was developed and revealed the presence of the RSDaV in several rose cultivars. RSDaV-inoculated rose plants developed RSD symptoms, confirming its role in the etiology of the disease.
\end{abstract}

Additional keywords: aphid transmission, cryptic virus

Roses are the most popular garden plants in the world as well as the most important cut flowers grown under cover. A number of virus diseases with various symptoms have been described as occurring naturally on roses. Viruses that infect roses mostly belong to the genera Ilarvirus and Nepovirus. Among ilarviruses, Prunus necrotic ringspot virus (PNRSV) has been isolated in many rose-growing regions worldwide (9) and Apple mosaic virus (ApMV) mainly in the United States, New Zealand, and Australia $(8,16)$. Tobacco streak virus (TSV) has been observed occasionally in roses in the United States where it induced severe symptoms (2). More recently, a new Ilarvirus, Blackberry chlorotic ringspot virus (BCRV), has been found in the midwestern and southwestern United States (31). Among nepoviruses, Arabis mosaic virus (ArMV) and Strawberry latent ringspot virus (SLRSV), alone or in complexes with ilarviruses, infected garden and greenhouse roses in Great Britain (15). Tobacco ringspot virus (TRSV) and Tomato ringspot virus (ToRSV) have

Corresponding author: A. Rowhani

E-mail: akrowhani@ucdavis.edu

Accepted for publication 21 November 2007.

doi:10.1094/PDIS-92-4-0508

(C) 2008 The American Phytopathological Society been isolated from rose in the United States (19).

Several virus-like diseases of uncertain etiology also have been reported in roses $(14,25)$. One of these is rose spring dwarf disease (RSD). RSD is found in commercial nurseries, landscape roses, and public rose gardens in California (25). RSDaffected plants exhibit distinct symptoms in hybrid tea rose cultivars and in the rootstock and indicator cv. Rosa multiflora Thunb. cv. Burr (26). RSD-affected plants show rosetting or a "balled" appearance in the new growth following bud break. Newly emerged leaves are short and show conspicuous vein clearing or a netted appearance (Fig. 1). These symptoms become less apparent as shoots eventually elongate. Canes may develop a zigzag pattern of growth as the season progresses (26).

Rose plants are often symptomless carriers of these viruses. Virus transmission occurs mostly through propagation of infected material; therefore, control is best achieved by using virus-tested stock from a clean plant program. Foundation Plant Services (FPS) is a self-supporting service department within the College of Agriculture and Environmental Sciences at the University of California, Davis, (UC Davis) which produces, tests, maintains, and distributes a public collection of virustested roses. Limited funding for the program has restricted the frequency with which both laboratory and biological indexing tests can be performed for the more than 500 rose scion and rootstock selections in the collection. However, in the last decade, the Garden Rose Council (an association of commercial garden rose nurseries) has funded increased testing for the collection. Routine screening now includes regular enzyme-linked immunosorbent assay (ELISA) testing for ApMV and PNRSV, the viruses most commonly found in roses in California (10), as well as biological indexing on Shirofugen cherry and $R$. multiflora (23). In the course of $R$. multiflora indexing, a graft-transmissible disease of putative viral etiology was discovered (24) in a number of rose accessions, which subsequently were removed from the collection. This disease was largely asymptomatic in rose scion cultivars; however, on $R$. multiflora, the symptoms were consistent with RSD.

Plants with these symptoms did not give any positive results in reverse-transcription polymerase chain reaction (RT-PCR) and ELISA tests for Apple chlorotic leaf spot virus (ACLSV), ApMV, ArMV, PNRSV, SLRSV, ToRSV, TRSV, and TSV. To test the hypothesis that the disease was caused by a plant virus associated with the RSD, we tried to isolate double-stranded RNA (dsRNA) as a typical indicator of RNA virus infection $(5,6,32)$. In the course of our studies, we were able to obtain a reproducible dsRNA pattern, which indicated infection with an RNA virus associated with the RSD (24). In this study, we report the initial molecular characterization of a virus associated with RSD and designate it as rose spring dwarf associated virus (RSDaV). Phylogenetic analysis revealed that the virus was closely related to members of the genus Luteovirus in the family Luteoviridae. Furthermore, the natural vector of the virus and its host range were studied and an RT-PCR method for its detection was developed.

\section{MATERIALS AND METHODS}

Virus source and testing. The RSDaVinfected Hybrid tea rose cv. Rose of Freedom plants used in this study were ownrooted cuttings of the original plant grown in the field. The original source tested positive when indexed by grafttransmission on the indicator plant $R$. $m u l$ tiflora. The source plant was tested for the presence of different viruses (ACLSV, ApMV, ArMV, PNRSV, SLRSV, ToRSV, 
TRSV, and TSV) by mechanical inoculation to Chenopodium quinoa, Cucumis sativus, and Nicotiana tabacum or by RTPCR $(19,21)$ and double-antibody sandwich (DAS)-ELISA) (22,30). Immunoglobulins (IgGs) and alkaline phosphate conjugate of the above viruses were obtained from Bioreba Ag (Reinach, Switzerland).

dsRNA extraction and cDNA synthesis. For dsRNA extraction, $30 \mathrm{~g}$ of bark scrapings were collected and powdered in liquid nitrogen. dsRNA was extracted using two cycles of CF-11 (Whatman, Springfield Mill, England) column chromatography (32). After purification, the total dsRNAs were treated with ribonuclease $A$, proteinase $\mathrm{K}$, and deoxyribonuclease $\mathrm{I}$, to eliminate contaminating singlestranded (ss)RNA, ssDNA, and dsDNA (7). cDNAs were synthesized using dsRNAs as templates. Initially, dsRNAs were denatured with $20 \mathrm{mM}$ methyl mercuric hydroxide and heating at $94^{\circ} \mathrm{C}$ for 5 min. The SuperScript Choice System for cDNA synthesis (Invitrogen Corp., Carlsbad, CA) was used to construct a cDNA library from viral RNA following the manufacturer's instructions. The doublestranded cDNAs were ligated into pGEMT Easy (Promega Corp., Madison, WI) and transformed into Escherichia coli 10G supreme electrocompetent cells (Lucigen Corp., Middleton, WI). Recombinant colonies were selected and grown in LuriaBertani broth containing ampicillin at 100 $\mu \mathrm{g} / \mathrm{ml}$ (Sigma-Aldrich, St. Louis). Plasmids were purified using the FastPlasmid Mini (Eppendorf, Westbury, NY), and digested with EcoR1 to determine the insert size.

Sequencing and phylogenetic analysis. Clones containing cDNA inserts were identified and nucleotide sequencing was performed on both cDNA strands using an AB1373 Automated Sequencer at the University of California (Davis). Blastn and

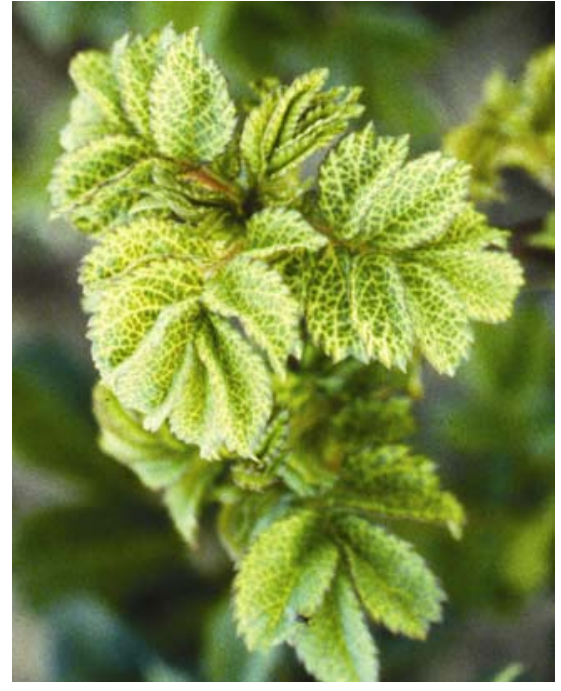

Fig. 1. Symptoms of rose spring dwarf disease on Rosa multiflora plant. blastx (1) were utilized to identify RSDaVspecific sequences and then were used to construct a consensus nucleotide sequence. Sequences were analyzed using sequence analysis and data management software from Invitrogen (Vector NTI Advance 10). The amino acid sequences of partial RNAdependent RNA polymerase ( $R d R p)$ and coat protein (CP) of RSDaV and of corresponding sequences from members of the Luteoviridae family were analyzed using ClustalX (29). Phylogenetic trees were constructed using MEGA2 software (17).

RT-PCR and virus detection. The sequence data were utilized to design RSDaV-specific primers for virus detection in different rose cultivars. For most RTPCR assays, LutRev (5'-GGGACGTCG CTACCTGCTGGAAAT-3') and LutFor (5'-TGGCGCCACCTGGAATGTAGG-3') were used to amplify a 418-nucleotide (nt) fragment from the $\mathrm{CP}$ gene of RSDaV. The template for RT-PCR reactions was either dsRNA extracted as described above or total RNA extracted using the RNeasy kit (Qiagen, Valencia, CA) following the manufacturer's instructions. A one-step RT-PCR protocol was used (21) in a $25-\mu l$ reaction volume containing $2.5 \mu \mathrm{l}$ of $10 \times$ PCR buffer, $1.1 \mu \mathrm{l}$ of $25 \mathrm{mM} \mathrm{MgCl} 2,1.25$ $\mu \mathrm{l}$ of $0.1 \mathrm{M}$ dithiothreitol, $0.5 \mu \mathrm{l}$ of $10 \mathrm{mM}$ dNTPs, $1.25 \mu \mathrm{l}$ of each primer $(10 \mu \mathrm{M})$, $0.25 \mu \mathrm{l}$ of $\mathrm{Taq}$ polymerase (5 units $/ \mu \mathrm{l}$, Promega, Corp.), and $0.035 \mu \mathrm{l}$ of Super Script II reverse transcriptase (200 units/ $\mu$, Invitrogen Corp.). Reactions consisted of one cycle of $52^{\circ} \mathrm{C}$ for $30 \mathrm{~min} ; 35$ cycles of $94^{\circ} \mathrm{C}$ for $30 \mathrm{~s}, 54^{\circ} \mathrm{C}$ for $45 \mathrm{~s}$, and $72^{\circ} \mathrm{C}$ for $1 \mathrm{~min}$; and a final $72^{\circ} \mathrm{C}$ extension for 10 min. PCR products were analyzed in $1.5 \%$ agarose gel electrophoresis in Tris-acetateEDTA buffer and visualized by ethidium bromide staining. Validation of the specificity of the RT-PCR was done by cloning and sequencing of several amplicons from different plants. To evaluate the prevalence of RSDaV in the field, collections of rose cultivars and $R$. multiflora samples from the virus-indexed rose blocks at FPS were tested for the presence of the new virus using this RT-PCR assay.

Vector transmission and host range studies. Five aphid species, including the green peach aphid (Myzus persicae), rosegrass aphid (Metapolophium dirhodum), rose aphid (Macrosiphium rosae), yellow rose aphid (Rhodobium porosum), and Wahlgreniella nervata, were used for vector transmission studies. Myzus persicae was reared on healthy radish (Raphanus sativus); Metapolophium dirhodum was reared on healthy barley (Hordeum vulgare); and Macrosiphium rosae, Rhodobium porosum, and $W$. nervata were reared on virus-tested healthy roses (Rosa multiflora). Plants that tested positive for RSDaV by RT-PCR were used as sources of inoculum for transmission studies described below. Several hundred individuals of each aphid species were given a 48-h acquisition access period on RSDaVinfected rose. Approximately 15 to 20 viruliferous aphids then were transferred onto healthy rose plants that RT-PCR tested for the absence of RSDaV and other viruses as well. After an inoculation access period of $48 \mathrm{~h}$, plants were treated with Bifenthrin (Ortho). In each experiment, at least 50 aphids from each group of colonies (virus-free aphids) were transferred onto healthy roses for a 48-h acquisition access period followed by a 48-h inoculation access period as controls.

Preliminary experiments were performed to determine if Rhodobium porosum was able to transmit RSDaV from infected roses to different plant species belonging to five botanical families (Brassicaceae: Capsella bursa-pastoris; Chenopodiaceae: Chenopodium amaranticolor

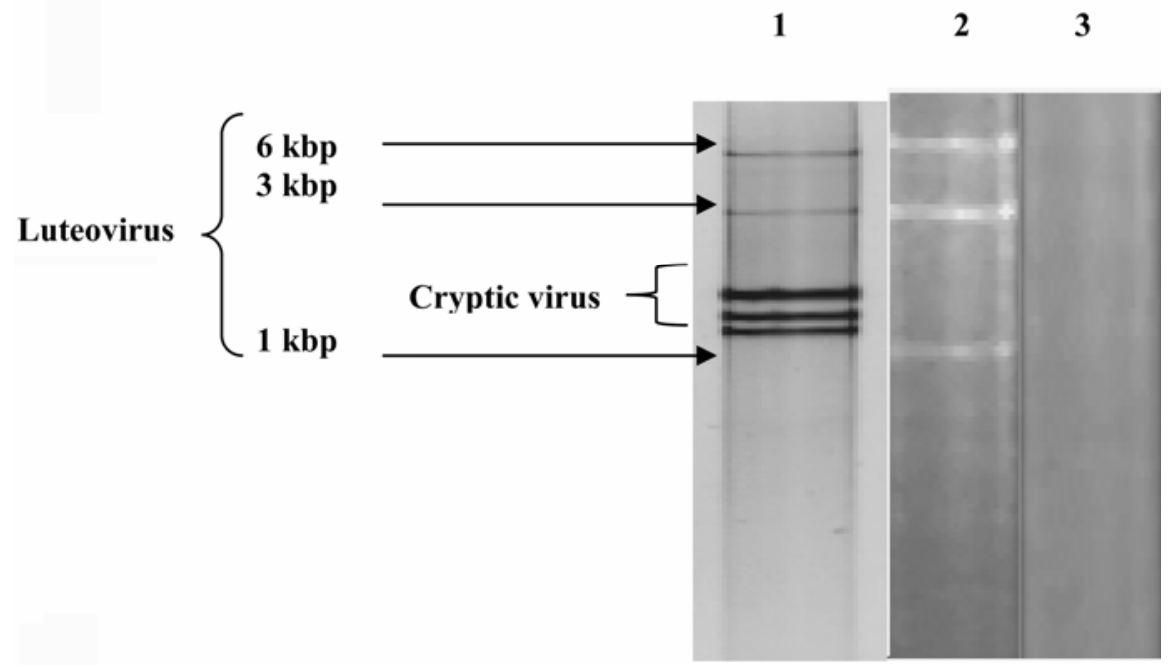

Fig. 2. Polyacrylamide gel electrophoresis (6\% in Tris-acetate-EDTA) of double-stranded RNA from rose spring dwarf associated virus (RSDaV)-infected plants. Lane 1, RSDaV-infected Rosa 'Rose of freedom'; lane 2, RSDaV-infected Rosa multiflora; and lane 3, healthy R. multiflora. Lane 1 was obtained from a silver-stained gel and lanes 2 and 3 from an ethidium bromide-stained gel. 

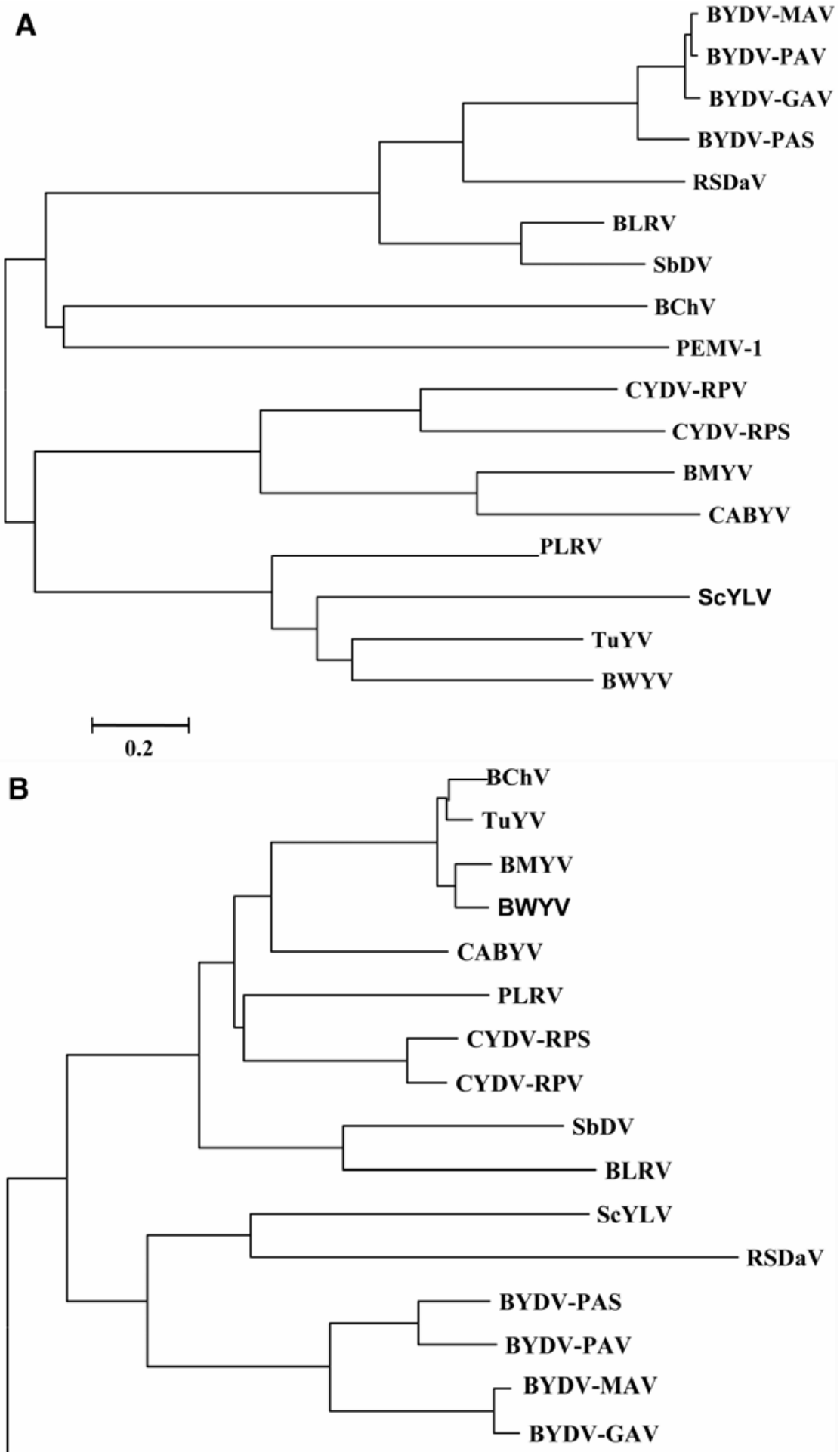

PEMV-1

0.1

Fig. 3. Phylogenetic relationships between rose spring dwarf associated virus (RSDaV) and other viruses from the family Luteoviridae. A, Partial RNA-dependent RNA polymerase (1,121 nucleotides) and $\mathbf{B}$, the coat protein (659 nucleotides). Trees were constructed with MEGA2. The bars represent substitutions per site. Viruses used in the comparison included Barley yellow dwarf virus-GAV (BYDVGAV), NC_004666; Barley yellow dwarf virus-MAV (BYDV-MAV), NC_003680; Barley yellow dwarf virus-PAS (BYDV-PAS), NC_002160; BYDV-PAV, NC_004750; Bean leafroll virus (BLRV), NC_003369; Beet chlorosis virus (BChV), NC_002766; Beet mild yellowing virus (BMYV), NC_003491; Beet western yellows virus (BWYV), NC_004756; Cereal yellow dwarf virus-RPS (CYDV-RPS), NC_002198; CYDV-RPV, NC_004751; Cucurbit aphid-borne yellows virus (CABYV), NC_003688; Pea enation mosaic virus-1 (PEMV-1), NC_003629; Potato leafroll virus (PLRV), NC_001747; Soybean dwarf virus (SbDV), NC_003056; Sugarcane yellow leaf virus (ScYLV), NC_000874; and Turnip yellows virus (TuYV), NC_003743. and C. quinoa; Compositae: Lactuca sativa; Cucurbitaceae: Cucumis sativus; and Solanaceae: $N$. benthamiana, $N$. clevelandii, and $N$. megalosiphon). $R$. porosum were fed on RSDaV-infected rose plants and 20 viruliferous aphids were transferred onto each test plant for inoculation as described above. In a different transmission study, the ability of Metapolophium dirhodum to transmit RSDaV from infected roses to healthy barley and oat was tested. After spraying with an insecticide, the plants were kept in an insect-free glasshouse and observed for symptom development. All inoculated plants were tested individually for virus infection by RT-PCR as described above. Both vector transmission and host range experiments were repeated three times.

\section{RESULTS}

Virus testing and dsRNA extraction. None of the herbaceous hosts used for mechanical transmission of RSDaV developed symptoms. RT-PCR and ELISA failed to detect ACLSV, ApMV, ArMV, PNRSV, SLRSV, ToRSV, TRSV, and TSV. dsRNA extractions and analyses revealed the presence of several dsRNA bands. The dsRNA pattern was similar to those reported for other luteoviruses $(3,28)$, including the presence of an approximately 6-kb molecule and the two smaller molecules, possibly of the subgenomic RNAs (Fig. 2). However, three additional minor dsRNA bands were detected in RSDinfected Rosa multiflora plants as well as in some healthy $R$. multiflora (data not shown) and were subjected to further analysis.

Partial sequencing and phylogenetic analysis. Molecular cloning of RSDaV dsRNAs yielded thousands of recombinant clones, 300 of which were analyzed by plasmid isolation, restriction enzyme digestion, and sequencing. The sizes of these clones ranged between 200 and 1,800 bp. A consensus nucleotide sequence of approximately 3,000 nt from 28 independent clones was constructed and predicted to compose part of the $\mathrm{RdRp}$ and $\mathrm{CP}$ sequences. In general, both strands of all clones were sequenced and $90 \%$ of the genome was determined from at least three independent cDNA clone. Sequence analysis from different clones showed similarities between the amplified sequence and open reading frame (ORF) 2 and ORF 3 from members of the family Luteoviridae; therefore, all further comparisons were limited to members of this family. Amino acid sequence analysis of partial RdRp and $\mathrm{CP}$ revealed significant similarities with corresponding $\mathrm{RdRp}$ and $\mathrm{CP}$ regions of other members of the family Luteoviridae, with the highest amino acid sequence similarity found with Soybean dwarf virus $(36 \%)$ and Sugarcane yellow leaf virus (44\%), respectively. These analyses were confirmed by the phylogenetic trees con- 
structed for RdRp and CP, which are shown in Figure 3. For both the RdRp and the $\mathrm{CP}$ trees, RSDaV was found to be closer to members of the genus Luteovirus than to members of the genera Enamovirus and Polerovirus.

Virus detection. The RT-PCR assay developed for specific detection of RSDaV gave the expected amplicon size (418 bp; Fig. 4). Sequencing and sequence comparisons of 10 PCR amplicons obtained from different host species or cultivars (barely, oat, and roses) showed 99\% nucleotide and amino acid identity with the same segment of the genome. To evaluate the prevalence of RSDaV, collections of Rosa spp. were tested for RSDaV using specific RT-PCR. In this test, RSDaV was detected in many different rose species and cultivars from the Foundation Rose Collection at FPS. In all, 129 plants in this collection were tested, and 77 were positive for RSDaV. Some of the hybrid rose cultivars tested positive for RSDaV included Queen Elizabeth, China Doll, Heirloom, Lowell Thomas, Jack Frost, New Dawn, Uncle Joe, Bridal White, Butterscotch, and Cynthia. It is interesting that the virus was detected in more than 69 plants in two rows (total number of plants in these rows was 89) of the collection which were planted in the mid 1990s. In all, 162 samples of $R$. multiflora from the virusindexing rose blocks also were assayed in the spring and RSDaV was found in 94 plants. The majority of RT-PCR-positive $R$. multiflora plants were symptomatic. Another 40 additional plants from the same virus-indexing blocks were tested in the summer and 6 were positive. Generally, virus-infected plants look healthy under summer growing conditions.

Vector transmission and specificity. In three transmission experiments using acquisition and inoculation access periods of $48 \mathrm{~h}$ each, only rose plants that were inoculated with the virus using Metapolophium dirhodum and Rhodobium porosum developed RSD symptoms 4 to 6 weeks after inoculation, and they also tested positive for RSDaV with RT-PCR (data not shown). Symptoms included interveinal yellowing accompanied by thickening and brittleness of the leaves. However, symptoms observed in roses were less severe under glasshouse conditions than those observed in the original plants in the field, perhaps due to differences in the environmental conditions. None of the plants inoculated using Myzus persicae, Macrosiphum rosae, or $W$. nervata developed symptoms or tested positive by RT-PCR. This indicated that, of the five aphid species tested, only Metapolophium dirhodum and Rhodobium porosum were vectors of RSDaV (Table 1).

Host range and symptomatology. Of the eight different herbaceous plant species inoculated with RSDaV using $R$. porosum as vector, virus was transmitted only to $N$. benthamiana. Despite repeated inoculation attempts (three independent experiments), RSDaV was not detected in other herbaceous plant species tested.

Barley and oat plants inoculated with $\mathrm{RSDaV}$ using $M$. dirhodum as the vector did test positive by RT-PCR for RSDaV (data not shown). However, all plants remained asymptomatic during the course of this study. When RSDaV-inoculated oat plants were tested 3 weeks post inoculation, they were positive for the presence of RSDaV. Furthermore, M. dirhodum individuals were permitted a 48-h acquisition access period on leaves of RSDaV-infected oat and then transferred to more oat and barley plants. Attempts to use M. dirhodum to transmit RSDaV from RSDaV-infected oat into barley and oat were successful; however, inoculated plants failed to develop visible symptoms.

\section{DISCUSSION}

We show for the first time an association of a virus with RSD, an important disease of roses (26). We have tentatively named this virus rose spring dwarf associated virus (RSDaV). Rosa multiflora plants either graft-inoculated with scions from RSDaV-infected plants or inoculated with M. dirhodum or Rhodobium porosum fed on RSDaV-infected roses developed typical RSD symptoms, indicating the role of
RSDaV in RSD etiology. The percent identities and phylogenetic analysis of the RSDaV CP and partial RdRp amino acid sequences strongly suggested that RSDaV belongs to the family Luteoviridae. Also, both the CP and RdRp amino acid sequences favored classification of the virus in the genus Luteovirus. Because the similarities in $\mathrm{CP}$ amino acid sequences of $\mathrm{RSDaV}$ and other luteoviruses ranged from 36 to $44 \%$, it was not surprising that the broad-range luteovirus monoclonal antibody 5G4 (AS-0227; DSMZ, Braunschweig, Germany; 27) did not detect RSDaV virions in Western blot and tissue blot immunoassay (data not shown). These data, together with our inability to amplify any DNA fragments using different virusspecific primers, strongly suggest that $\mathrm{RSDaV}$ is associated with RSD in roses. ELISA results suggested the absence of ACLSV, ApMV, ArMV, PNRSV, SLRSV, ToRSV, TRSV, and TSV, although some of these viruses have been reported to occur frequently in roses (14).

The luteoviruses (family Luteoviridae) are a large group of plant viruses which cause economically significant yellowing diseases in a wide range of hosts (13). These viruses are genetically diverse but collectively share several features clearly distinct from other plant viruses. These features included phloem restriction,

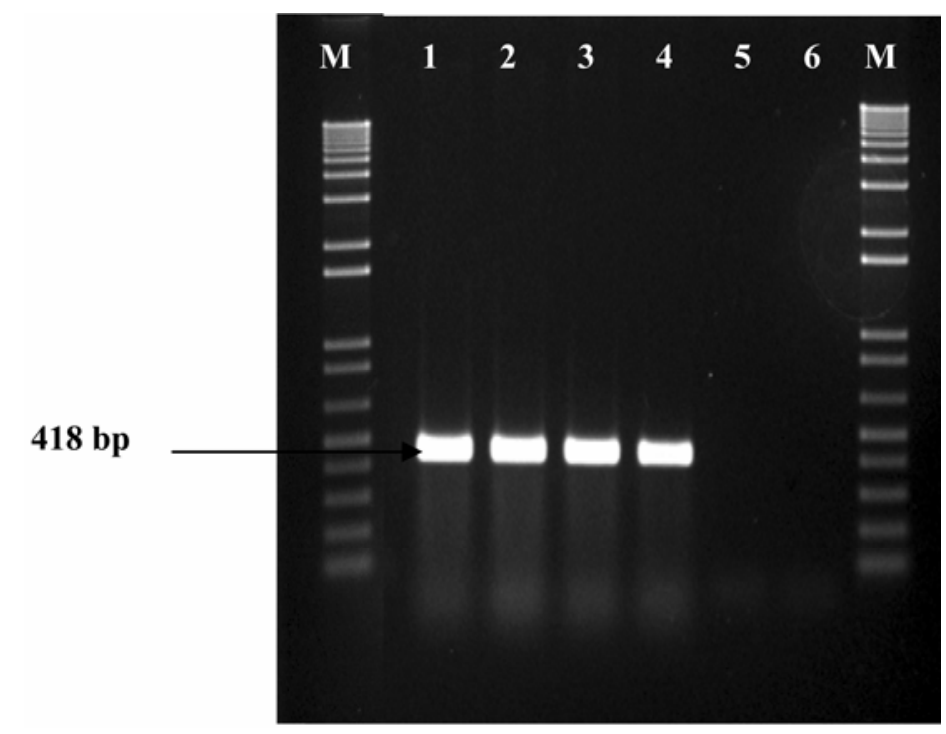

Fig. 4. Reverse-transcription polymerase chain reaction detection of rose spring dwarf associated virus $(\mathrm{RSDaV})$. The products were electrophoresed on 1.5\% agarose gel. Lanes 1, 2, 3, and 4, samples from Rosa multiflora showing rose spring dwarf disease symptoms; lane 5, healthy; lane 6, water; and M, 1kb-plus DNA ladder.

Table 1. Aphid transmission of rose spring dwarf associated virus (RSDaV)

\begin{tabular}{lcc}
\hline Aphid species $^{\mathbf{a}}$ & Plants infected/plants inoculated & ${\text { Infection }(\boldsymbol{\%})^{\mathbf{b}}}^{\text {Myzus persicae }}$ \\
Metapolophium dirhodum & $0 / 42$ & 0 \\
Macrosiphium rosae & $15 / 24$ & 63 \\
Rhodobium porosum & $0 / 22$ & 0 \\
Wahlgreniella nervata & $30 / 81$ & 37 \\
\hline
\end{tabular}

a Aphids were allowed a 48-h virus acquisition access period and 48-h virus inoculation access period.

b Virus infection confirmed by reverse-transcription polymerase chain reaction. 
transmission by aphids in a persistent circulative manner, lack of mechanical transmission, high degree of vector specificity, host range restriction often to a single plant family, and serological relationships between most members of the family (18). The family has been classified into three major genera (Luteovirus, Polerovirus, and Enamovirus) on the basis of their genomic organization, replication strategies, and expression mechanisms (4).

In addition to the molecular properties, we also provided biological evidence for the occurrence of a new Luteovirus in roses. Our attempts to biologically characterize RSDaV were concentrated on identifying its aphid vectors and determining its experimental host range. Of the five aphid species tested, only $M$. dirhodum and $R$. porosum transmitted RSDaV, suggesting a high level of vector specificity as is commonly observed for luteoviruses (11). $M$. dirhodum has been reported as a vector of BYDV-PAV (12) and feeds on both roses and grasses; therefore, this aphid was tested as an RSDaV vector. $M$. dirhodum was a relatively efficient vector of RSDaV. Host range data showed that RSDaV has a host range including monocots (barley and oat) as well as dicots. This divergent host range may be partially related to the aphid species that transmit RSDaV. The rosegrass aphid is an efficient vector of $\mathrm{RSDaV}$ and its host range also includes monocots and dicots. The data reported here are similar to previous studies that have shown that the host range of BWYV, a polerovirus, also is not limited only to dicotyledonous plants, but oat plants (Avena byzantina) also were susceptible to the virus $(7,20)$.

The RT-PCR detection technique described here will be used for RSDaV detection and identification, for determination of its diversity, and for assessment of its relative importance as a disease. RSDaV was detected mainly in two rows of the Foundation Rose Collection. This distribution is suggestive of root grafting in addition to the possibility of vector spread. Earlier work suggested that root grafting is a mechanism of virus spread in roses for viruses associated with rose mosaic (10).

Although we have isolated and characterized a virus from an RSD-infected rose and established a good correlation between this virus and the disease by RT-PCR and by vector transmission and symptomatology, more research is required to clearly establish the causal relationship.

The majority of asymptomatic Rosa multiflora plants used as indicator host for RSD also were infected with a cryptic virus (Fig. 1) based on dsRNA analysis and limited sequencing and sequence analysis (data not shown). However, the role of this cryptic virus in RSD sympto- matology is not clear and requires further research.

\section{ACKNOWLEDGMENTS}

N. Salem is grateful to FULBRIGHT for a postdoctoral fellowship. This project was also partially supported by funding from the Garden Rose Council. We thank S. Gray (United States Department of Agriculture-Agricultural Research Service, Cornell University) for providing the rose-grass aphid; D. Stephan (University of Hannovor, Germany) for providing the 5G4 antiserum; and A.-L. Moyne, S. T. Sim, J. Lee, and M. Cunningham (Foundation Plant Services, University of California, Davis) for their assistance.

\section{LITERATURE CITED}

1. Altschul, S. F., Madden, T. L., Schäffer, A. A., Zhang, J., Zhang, Z., Miller W., and Lipman, D. J. 1997. Gapped BLAST and PSIBLAST: a new generation of protein database search programs. Nucleic Acids Res. 25:3389-3402

2. Converse, R. H., and Bartlett, A. B. 1979. Occurrence of viruses in some wild Rubus and Rosa species in Oregon. Plant Dis. Rep. 63:441-444.

3. Damsteegt, V. D., Stone, A. L., Russo, A. J., Luster, D. G., Gildow, F. E., and Smith, O. P. 1999. Identification, characterization, and relatedness of luteovirus isolates from forage legumes. Phytopathology 89:374-379.

4. D'Arcy, C. J., and Domier, L. L. 2005. Family Luteoviridae. Pages 343-352 in: Virus Taxonomy. Eighth Report of the International Committee on Taxonomy of Viruses. C. M. Fauquet, M. A. Mayo, J. Maniloff, U. Desselberger, and L. A. Ball, eds. Academic Press, San Diego, CA.

5. Dodds, J. A. 1993. dsRNA in diagnosis. Pages 274-289 in: Diagnosis of Plant Virus Diseases. R. E. F. Matthews, ed. CRC Press, Boca Raton, FL.

6. Dodds, J. A., Morris, T. J., and Jordan, R. L. 1984. Plant viral double-stranded RNA. Annu. Rev. Phytopathol. 22:151-168.

7. Duffus, J. E., and Rowchow, W. F. 1978. Neutralization of beet western yellows virus by antisera against barely yellow dwarf virus. Phytopathology 68:45-49.

8. Fulton, R. 1967. Purification and serology of rose mosaic virus. Phytopathology 57:11971201

9. Fulton, R. 1970. Prunus necrotic ringspot virus. Descriptions of Plant Viruses. No. 5. Commonwealth Mycological Institute and Association of Applied Biologist, Ferry Lane, Kew, Surrey, England.

10. Golino, D. A., Sim, S. T., Cunningham, M., and Rowhani. A. Transmission of rose mosaic viruses. In: Proc. 2005 ISHS Rose Meeting. Santa Barbara, CA. In press.

11. Gray, S. M., and Gildow, F. E. 2003. Luteovirus-aphid interactions. Annu. Rev. Phytopathol. 41:529-566.

12. Halbert, S., and Voegtlin, D. 1995. Biology and taxonomy of vectors of barley yellow dwarf viruses. Pages 217-258 in: Barley Yellow Dwarf: 40 years of Progress, C. J. D'Arcy and P. A. Burnett, eds. American Phytopathological Society Press, St. Paul, MN

13. Harisson, B. D. 1999. Steps in the development of Luteovirology. Pages 1-41 in: The Luteoviridae. H. Smith and H. Backer, eds. CABI Publishing, Wallingford, Oxon, England.

14. Horst, R. K. 1999. Compendium of Rose Diseases. American Phytopathological Society Press, St. Paul, MN

15. Ikin, R., and Frost, R. R. 1976. Virus diseases of roses. Part 1. Their occurrence in the United Kingdom. Phytopathol. Z. 87:205-223.

16. Johnstone, G., Munro, R. D., Brown, G. S., and Skotland C. B. 1995. Serological detection, occurrence and spread of ilarviruses in temperate fruit crops, hops and roses in Tasmania. Acta Hortic. 386:132-135.

17. Kumar, S., Tamura, K., Jakobsen, I. B., and Nei, M. 2001. MEGA2: molecular evolutionary genetics analysis software. Bioinf. Appl. Note 17:1244-1245.

18. Martin, R. R., Keese, P., Young, M. J., Waterhouse, P. M., Waterhouse, P. M., and Gerlach, W. L. 1990. Evolution and molecular biology of luteoviruses. Annu. Rev. Phytopathol. 28:341-363.

19. Massuth, A., Pollari, E., Helmeczy, K., Stewart, S., and Kofalvi, S. A. 2000. Improved RNA extraction and one-tube RT-PCR assay for simultaneous detection of control plant RNA plus several viruses in plant extracts. J. Virol. Methods 90:37-49.

20. McDaniel, G. L., Buck, G. J., and Ford, R. E. 1971. Isolation of tobacco ringspot virus from rose. Phytopathology 61:45-49.

21. Rowhani, A., Biardi, L., Johnson, R., Saldarelli, P., Zhang, Y. P., Chin, J., and Green M. 2000. Simplified sample preparation method and one-tube RT-PCR for grapevine viruses. In: Proc. XIII Int. Council Study of Viruses and Virus-Like Diseases of the Grapevine. Adelaide

22. Rowhani, A., and Falk, B. W. 1995. Enzyme linked immunosorbent assay (ELISA) methods assay to certify pathogen (virus)-free plants. Pages 267-280 in: Plant Cell, Tissue and Organ Culture. O. L. Gamborg and G. C. Phillips, eds. Springer, New York.

23. Rowhani, A., Uyemoto, J. K., Golino, D., and Martelli, G. P. 2005. Pathogen, testing and certification of Vitis and Prunus species. Annu. Rev. Phytopathol. 43:261-278.

24. Salem, N., Falk, B., Golino, D., and Rowhani, A. 2006. Genomic characterization of a nove member of the Luteoviridae associated with rose spring dwarf disease. In: Am. Soc. Virol. 25th Annu. Meet. University of WisconsinMadison.

25. Secor, G. A., Kong, M., and Nyland, G. 1977. Rose virus and virus-like diseases. Calif. Agric. 31:4-7.

26. Slack, S. A., Traylor, J. A., Nyland, G., and Williams, H. E. 1976. Symptoms, indexing and transmission of rose spring dwarf disease. Plant Dis. Rep. 60:183-187.

27. Stephan, D., and Maiss, E. 2006. Biological properties of Beet mild yellowing virus derived from a full-length cDNA clones. J. Gen. Virol 87:445-449.

28. Sugars, J. M., Lennon, E. A., Plumb, R. T., and White, R. F. 1998. Sugar beet yellow net complex contains a luteovirus component. Plant Pathol. 47:89-94.

29. Thompson, J. D., Gibson, T. J., Plewniak, F., Jeanmougin, F., and Higgins, D. G. 1997. The CLUSTALX windows interface; flexible strategies for multiple sequence alignment aided by quality analysis tools. Nucleic Acids Res. 25:4876-4882.

30. Torrance, L., and Jones, R. A. C. 1981. Recent developments in serological methods suited for use in routine testing for plant viruses. Plant Pathol. 30:1-24.

31. Tzanetakis, I. E., Gergerich, R. C., and Martin, R. R. 2006. A new Ilarvirus found in rose. Plant Pathol. 55:568.

32. Valverde, R. A., Nameth, S. T., and Jordan, R. L. 1990. Analysis of double-stranded RNA for plant virus diagnosis. Plant Dis. 7:255258. 